OPEN ACCESS

Edited by:

Guy Nuyts,

Janssen Pharmaceutica, Belgium

Reviewed by:

Andrew Eggleston

Medtronic, Australia

Domenico Criscuolo,

Genovax, Italy

*Correspondence:

Mihajlo Jakovljevic sidartagothama@gmail.com; jakovljevicm@medf.kg.ac.rs

Specialty section:

This article was submitted to

Pharmaceutical Medicine and

Outcomes Research,

a section of the journal

Frontiers in Pharmacology

Received: 18 November 2015

Accepted: 21 January 2016

Published: 09 February 2016

Citation:

Jakovljevic M, Lazarevic M, Milovanovic O and Kanjevac T (2016)

The New and Old Europe: East-West Split in Pharmaceutical Spending.

Front. Pharmacol. 7:18.

doi: 10.3389/fphar.2016.00018

\section{The New and Old Europe: East-West Split in Pharmaceutical Spending}

\author{
Mihajlo Jakovljevic ${ }^{1 *}$, Marija Lazarevic ${ }^{1}$, Olivera Milovanovic ${ }^{2}$ and Tatjana Kanjevac ${ }^{3}$ \\ 1 Health Economics and Pharmacoeconomics, The Faculty of Medical Sciences, University of Kragujevac, Kragujevac, \\ Serbia, ${ }^{2}$ Department of Pharmacy, Faculty of Medical Sciences, University of Kragujevac, Kragujevac, Serbia, ${ }^{3}$ Department \\ for Preventive and Pediatric Dentistry, Faculty of Medicine, University of Kragujevac, Kragujevac, Serbia
}

\section{HIGHLIGHTS}

- Since the geopolitical developments of 1989, former centrally planned economies of Eastern Europe followed distinctively different pathways in national pharmaceutical expenditure evolution as compared to their free market Western European counterparts.

- Long term spending on pharmaceuticals expressed as percentage of total health expenditure was falling in free market economies as of 1989. Back in early 1990s it was at higher levels in transitional Eastern European countries and actually continued to grow further.

- Public financing share of total pharmaceutical expenditure was steadily falling in most Central and Eastern European countries over the recent few decades. Opposed scenario were EU-15 countries which successfully increased their public funding of prescription medicines for the sake of their citizens.

- Pace of annual increase in per capita spending on medicines in PPP terms, was at least 20\% faster in Eastern Europe compared to their Western counterparts. During the same years, CEE region was expanding their pharmaceuticals share of health spending in eight fold faster annual rate compared to the EU 15.

- Private and out-of-pocket expenditure became dominant in former socialist countries. Affordability issues coupled with growing income inequality in transitional economies will present a serious challenge to equitable provision and sustainable financing of pharmaceuticals in the long run.

Keywords: Eastern Europe, Western Europe, centrally-planned economy, free market economy, pharmaceuticals, expenditure, spending, transition

JEL codes: 111 Analysis of Health Care Markets, I18 Government Policy Regulation Public Health, P2 Socialist Systems and Transitional Economies, P1 Capitalist Systems, P51 Comparative Analysis of Economic Systems, F6 Economic Impacts of Globalization

\section{INTRODUCTION}

Historical decades following WWII were marked with rapid industrialization and build-up of welfare states in most free-market economies. This trend was closely associated with health expenditures rising across 4\% GDP threshold which remained quite stable throughout entire XIX and first half of XX century (Getzen, 1990). After this phenomenon was described in the US it became common elsewhere but most prominent in Western Europe, Japan and British Commonwealth countries. Over the next half a century health expenditure doubled or even tripled 
in many of the richest OECD societies. Challenges to sustainability of health care funding gradually were more obvious and concerning for policy makers. Unlike capital investments in buildings, equipment, medical staff salaries etc. prescription and dispensing of pharmaceuticals soon was understood to be more manageable part of these costs (Carone et al., 2012).

European geopolitical destiny since the end of Cold War Era back in 1989 opened up many issues ultimately affecting costs of medical care provision. Large number of previously state controlled socialist economies have undergone profound health reforms adopting free-market model (Jakovljevic, 2013). Central and Eastern European Post-Semashko Soviet style health systems were characterized with higher number of (more) hospital beds, physician, and nursing staff densities compared to Western Europe (Semashko, 1934; Torosyan et al., 2008). Nevertheless, average length of hospital stay was much lengthier and these nations had curative, hospital based systems instead of preventive ones, driven by family medicine practices common in the West (Healy and McKee, 2002). The latter turned out to be far more effective in terms of resource use and health outcomes gained (Kornai and Eggleston, 2001).

Evidence based medicine and cost-effective resource allocation slowly became more common in Eastern European policy makers mindset (Jakovljevic et al., 2011). These changes were closely to the rapid growth of most CEE pharmaceutical markets since the middle 1990s and early 2000s (Jakovljevic et al., 2015a). Although drug acquisition costs clearly grew up in the old EU-15 pre-2004 members as well, this appears to have happened at the far slower pace (Nuijten et al., 2001). Basically similar upward trends in value based turnover and budget impact of medicines in East and West of European region were hiding distinctively different patterns. We decided to observe WHO issued European Health for All database (HFA-DB) in order to test this assumption.

\section{DATA REPORT METHODS}

\section{Public Data Sources Used}

WHO issued European Health for All database (HFA-DB) is a public registry with large number of data on demographics, health care resources and outcomes and medical service consumption data on all countries of the European Region (WHO, HFA-DB, 2015). It consists of regularly updated reports issued by WHO/European Office, the statistical office of the European Union (EUROSTAT), United Nations system, the Organization for Economic Cooperation and Development and data reported by the national authorities. Readers are free to access and reuse these publicly available data at the link provided beneath.

\section{Data}

Pharmaceutical spending is commonly defined as expenditures on prescription medicines and over-the-counter products without hospital consumption of pharmaceuticals (OECD Pharmaceutical Spending, 2013). Medical consumables are included in such data in many countries (approximately 5\% of reported value) and pharmacists' salaries if these are accounted separately from the price of medicines. Ultimately calculated total pharmaceutical expenditure assumes wholesale and retail margins and value-added tax.

Selected pharmaceutical spending indicators in this study were: Pharmaceutical expenditure expressed as percentage of total health expenditure, public pharmaceutical expenditure expressed as percentage of total pharmaceutical expenditure and pharmaceutical expenditure per capita expressed in purchase power parity terms (international \$). Time horizon observed was spreading from the earliest available evidence listed in HFADB back in 1970 to the last official updates in 2012.Targeted countries where were all 53 countries of the European Region divided in two groups based on their economic and health care historical legacies: free-market economies prior to 1989 (a total of 25dominantly Western European countries) and centrally planned socialist economies prior to 1989 (a total of 28dominantly Eastern European countries; Berend, 2006).Total of five nations among free-market economies and ten among former centrally planned economies were observed for missing relevant data and thus were excluded from observation.

\section{RESULTS}

Pharmaceutical expenditure (PE) percentage of total health expenditure used to be higher in centrally planned economies. Mean of historical bottom values was $20 \%$ growing toward $21.7 \%$ in recent years. This meant total $+3.0 \%$ net increase per country over 14.7 years long time horizon on average. Mean annual growth was calculated to be $+0.08 \%$. Unlike these, we notice exactly the opposed trend in free market economies. Their arithmetic mean of historical baseline values was $16.2 \%$. It felt toward $15.1 \%$ in contemporary period. Net change here was negative: average $-0.7 \%$ decrease over 33.5 years long time horizon on average. Length of observation here was longer because OECD economies pioneered reporting these data to WHO during the Cold War Era. Their mean annual growth was eight times slower, approximately $+0.01 \%$.

Observing the landscape of public pharmaceutical expenditure percentage point share of total health expenditure we come to entirely different mirror-like reflection. Centrally planned economies tended to have lower public participation in drug acquisition and dispensing costs (arithmetic mean of earliest reported values of $43.3 \%$ ) which was historically further falling toward $36.5 \%$ on average in recent years. This meant a total contraction of public spending on drugs of $-6.8 \%$ on average. This huge change happened over the course of 10.6 years (mean time span between first and last reported values in Eastern European states).This accounts for mean annual $-0.47 \%$ contraction of public spending on drugs. Free market nations recorded much higher average public share of $57.5 \%$ in earliest historical records back in 1970s. It has grown further up to $62.9 \%$ in recent years with a total net change of $+5.4 \%$ over 32.3 years (mean time span between first and last reported values in Western, Southern and Northern European states). Annual net change was positive amounting to $+0.16 \%$. This huge disparity 
presents the single most important finding of this data report (see Figure 1).

Pharmaceutical expenditure per capita expressed in purchase power parity (PPP) terms (international \$) allows for international comparability and these values introduce another perspective. Back in early 1970s free market economies were spending on medicines modest average amount of $\$ 68$ per capita which grew tremendously reaching mean value of $\$ 488$ in recent years. This meant net gain of $\$ 420$ on average with annual increment of $+\$ 12.30$ over 34.1 years (Table 1). Among most of the former centrally planned economies such data were lacking almost until the late 1990s. Therefore, we have come to a slightly distorted picture of mean $\$ 190$ per capita among the earliest reported values rising up to $\$ 427$ in recent years. Total increment of some $\$ 237$ was approximately twice lower compared to the West. Keeping in mind that this change refers to the average time span of 13.8 years between the earliest and last reported values, we come to the annual increment of $+\$ 16.89$ per capita (Table 2).

\section{DISCUSSION}

Long term spending on pharmaceuticals expressed as percentage of total health expenditure was falling in mature economies (Mossialos and Oliver, 2005).Back in the late 1980s and early 1990s it was at higher levels in transitional Eastern European countries and actually continued to grow (Mrazek et al., 2004). Opposed to this trend, free market, predominantly Western, Southern and Northern European states continued to contract participation of medicines in their national medical spending pattern. This effectively meant that other medical technologies mostly related to hospital care, such as radiology diagnostics, advanced surgery, interventional radiology and radiation oncology, laboratory tests, rehabilitating and mental health related medical services and social support programs were participating more significantly to the structure of medical spending (Robinson, 1994; Ackroyd et al., 2006; Jakovljevic et al., 2013, 2014a, 2015b; Ranković et al., 2013).

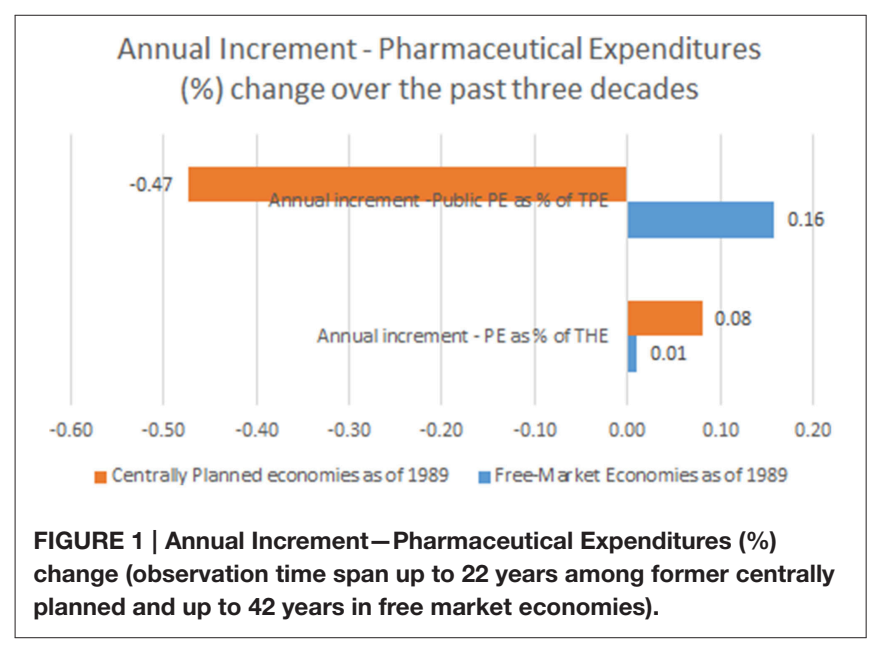

Public financing share of total pharmaceutical expenditure was steadily falling in most Central and Eastern European countries (Gotseva, 2015). It was at far lower, approximately one-third level, compared to their Western counterparts back in Cold War era (Jakovljevic et al., 2015d). Today, such changes coupled with rising budget impact of drug acquisition costs point out to the strong growth of patient cost-sharing mechanisms throughout the CEE region (Iskrov and Stefanov, 2015; Tambor et al., 2015). Out-of-pocket expenses and risks of catastrophic illness-induced household expenditure add to the complexity of this challenge (Jakovljevic, 2014a,b).

Opposed scenario were EU-15 countries successfully struggling to maintain and increase their public funding of prescription medicines for the sake of their citizens. They achieved extension in population coverage with cost-effective drug reimbursement strategies (Rémuzat et al., 2015). Thus, these countries were reducing exposure of vulnerable social groups to the issues affecting access to medicines. Although success rates across EU-15 differ significantly, most countries have adopted responsible pharmaceutical polices. National authorities besides, proved mostly capable of withstanding diverse financial constraints. Some were temporary such as the global economic recession while others such as medical innovation led primarily by brand pharmaceutical industry posed difficulties in the long run (Higgins and Graham, 2009; Dagovic et al., 2015). Huge budget impact of novel medicines such as monoclonal antibodies remains particularly hot topic sparkling debate among policy makers (Jakovljevic, 2014b).Some of the solutions found to release such pressures were incentives for generic substitution of brand name medicines (Jakovljevic et al., 2014b). With more or less legislative obstacles generic share in local markets expanded significantly over time (Simoens and De Coster, 2006).

Per capita spending on pharmaceuticals expressed in purchased power parity terms, points out to the joint strong growth of overall costs of prescribed and dispensed medicines and OTC agents (Ess et al., 2003). With regards to the historical perspective there appears to be no distinct difference in spending patterns among the two regions. The obvious fact was lag in Eastern European drug acquisition costs back in the late 1980s (Rhodes et al., 1999). Rapid increase in pharmaceutical expenditure since the 1990s followed, being one of the recognized mile stones of transitional health care reforms (Krajewski-Siuda and Romaniuk, 2006). Notable transformation of local CEE markets is the expanded presence of brand name medicines and diversification of payment mechanisms (Petrusic and Jakovljevic, 2015). Informal payments and widening income gaps affecting affordability of medicines remain the key challenges across the region (Ensor, 2004; Jakovljevic et al., 2015c).

\section{STUDY LIMITATIONS}

Some countries did not report official data on pharmaceutical spending for either some indicators or years within the time span observed. These missing data refer to a total of 5 nations among free-market economies and 10 countries among former centrally planned economies. Most cases of partially or entirely missing data refer to the countries with relatively small population size in 


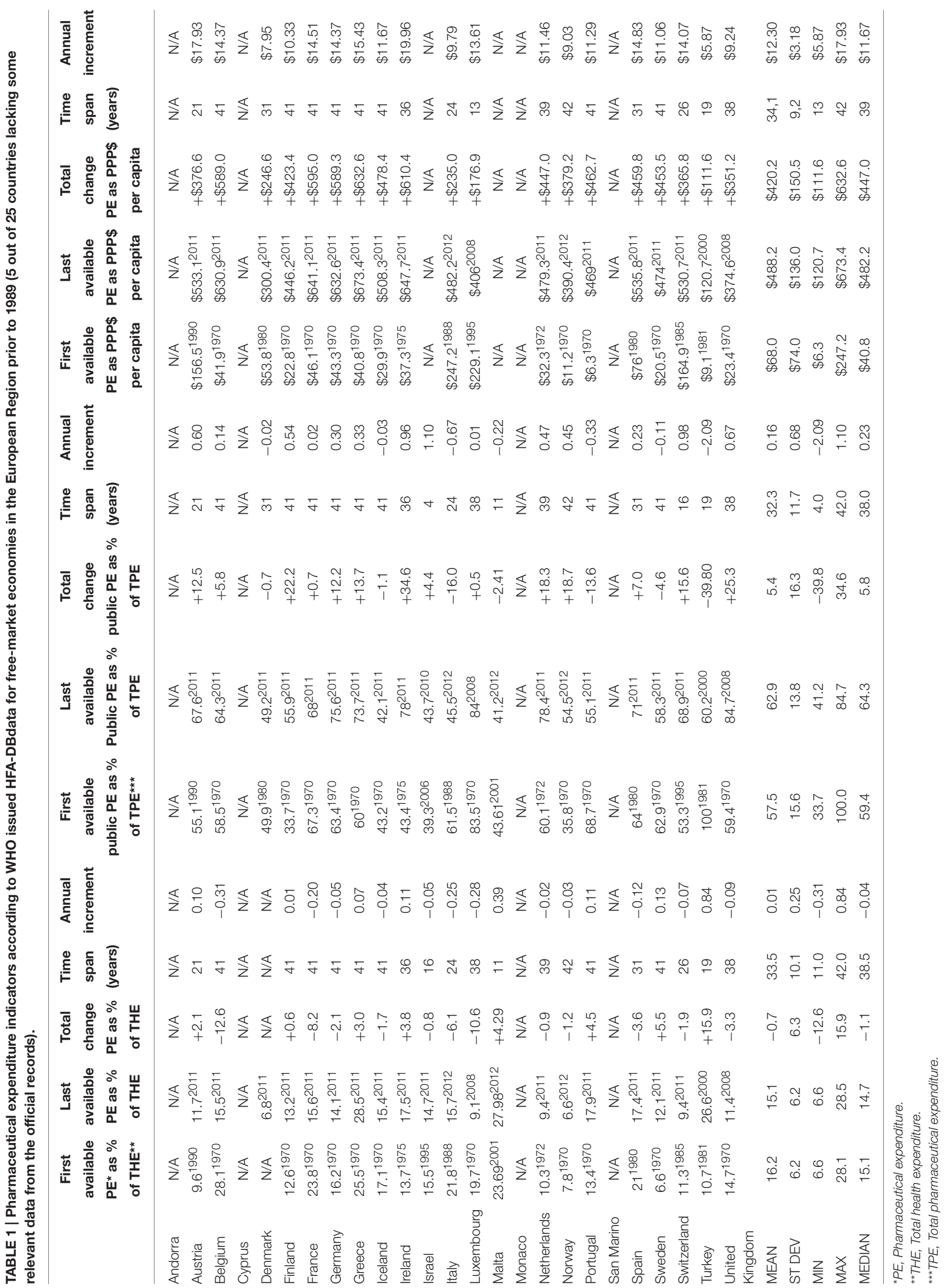




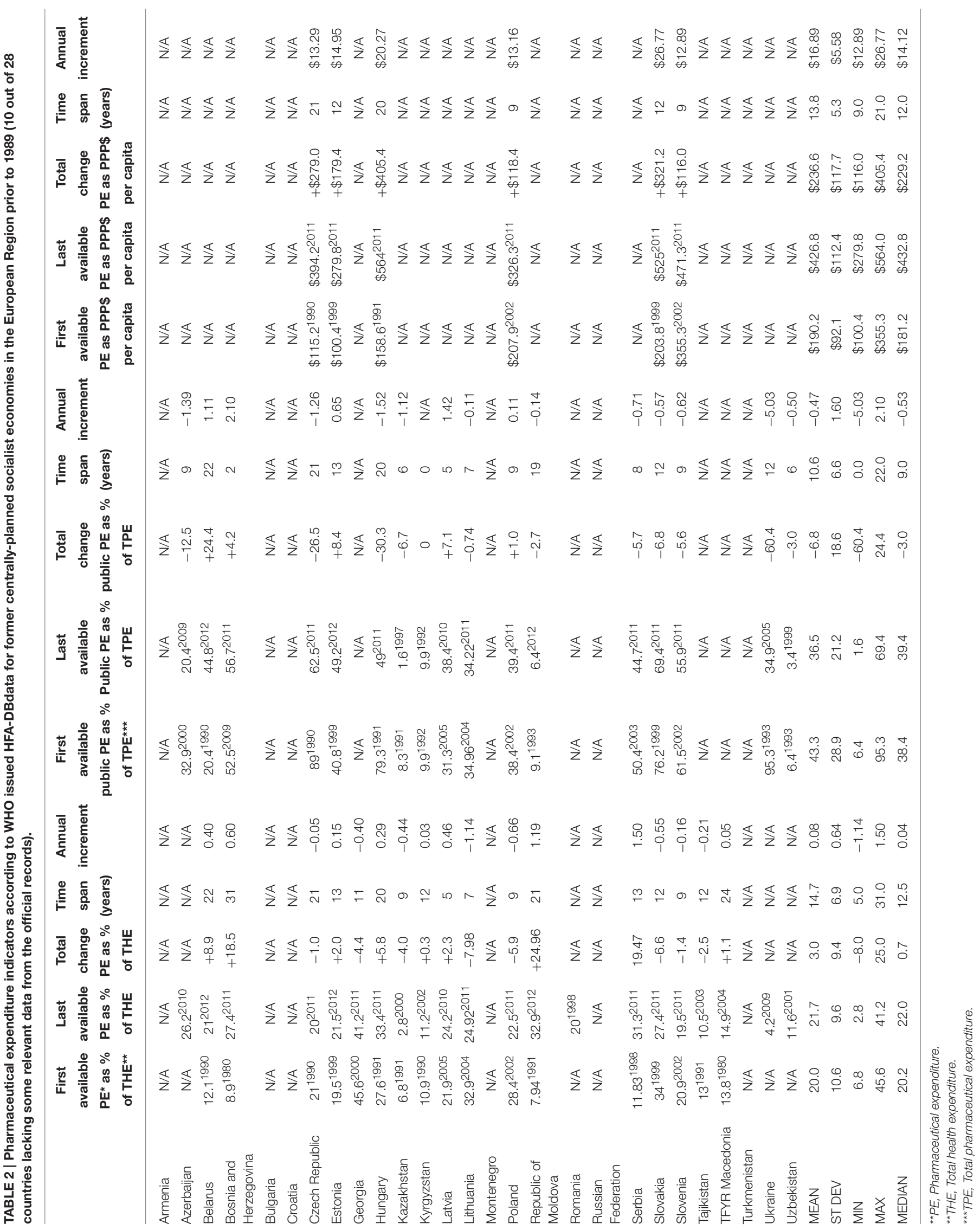


respective groups. Notable exceptions from this rule are Romania and Russian Federation. Russia was classified as a high income economy by the World Bank since August 2013 and as one of top performing emerging BRICS markets (The World Bank, 2015; Jakovljevic, 2016). Due to these facts we would like to limit our results and conclusions on the rest of Eastern European region as thus there is higher degree of homogeneity. Countries presented in the observed sample (20 of historical free market and 18 of centrally planned economies) are geographically scattered throughout the respective European regions. Therefore, we still regard observed sample of countries to be representative of broad long term trends in pharmaceutical spending in the European Region.

\section{CONCLUSION}

The two observed broad groups of countries, former centrally planned and free market economies, share profoundly different historical legacies in medicines provision and financing mechanisms (Mossialos et al., 2004). This data report provides insight into the existence of two distinctively different pathways in spending on drugs over past several decades in the East and West of Europe. National policies sharing public reimbursement, insurance based mechanisms and out-of-pocket spending appear to be headed in two different directions (Mackenbach, 2006). Eastern European states struggle with affordability issues and unequal access to medicines mostly determined by household income groups. Single most concerning fact is that transitional economies contracted their public share of pharmaceutical expenditure for almost half of percentage over the long course of years. Traditional free market economies, primarily EU-15 states mostly achieved better protection for their poor and vulnerable patient groups including those suffering from rare diseases and

\section{REFERENCES}

Ackroyd, R., Mouiel, J., Chevallier, J. M., and Daoud, F. (2006). Costeffectiveness and budget impact of obesity surgery in patients with type2 diabetes in three European countries. Obes. Surg. 16, 1488-1503. doi: $10.1381 / 096089206778870067$

Berend, I. T. (2006). An Economic History of Twentieth-Century Europe: Economic Regimes from Laissez-Faire to Globalization. Cambridge: Cambridge University Press. doi: 10.1017/cbo9780511800627

Carone, G., Schwierz, C., and Xavier, A. (2012). Cost-Containment Policies in Public Pharmaceutical Spending in the EU. European Economy. Available online at: http://ec.europa.eu/economy_finance/publications/ economic_paper/2012/pdf/ecp_461_en.pdf. (accessed October 15, 2015).

Dagovic, A., Zugic, A., and Jakovljevic, M. (2015). Macroeconomic policy impact on oncology-related public expenditure in an emerging european market-signs of early recovery. Serb. J. Exp. Clin. Res. 16, 43-50. doi: 10.1515/sjecr-2015-0007

Deacon, B. (2000). Eastern European welfare states: the impact of the politics of globalization. J. Eur. Soc. Policy 10, 146-161. doi: 10.1177/095892870001000203

Ensor, T. (2004). Informal payments for health care in transition economies. Soc. Sci. Med. 58, 237-246. doi: 10.1016/S0277-9536(03)00007-8

Ess, S. M., Schneeweiss, S., and Szucs, T. D. (2003). European healthcare policies for controlling drug expenditure. Pharmacoeconomics 21, 89-103. doi: 10.2165/00019053-200321020-00002 those requiring expensive treatment strategies (Iskrov et al., 2012). Nevertheless, we must point out the huge progress that was made in Eastern Europe providing access to the innovative medicines to the broad layers of population (Putrik et al., 2014). Pace of annual increase in per capita spending on medicines in PPP terms, was at least 20\% faster in Eastern Europe compared to their Western counterparts. During the same years CEE region was expanding their pharmaceuticals share of health spending in eight fold faster annual rate compared to the EU 15. Current difficulties to withstand pressures arising from population aging and prosperity diseases remain primary challenge for sustainable funding of medicines provision in all of Europe (Ogura and Jakovljevic, 2014; Jakovljevic and Milovanovic, 2015; Jakovljevic and Laaser, 2015). Although differences remain we believe that at some point in future, these regions will converge increasing social welfare and affordability of medicines to the ordinary citizens (Deacon, 2000).

\section{AUTHOR CONTRIBUTIONS}

MJ and TK developed research questions, designed the study and drafted most of the manuscript. ML and OM took part in data acquisition, mining and analysis and prepared the tables and figure. All four authors revised draft and contributed essentially to the final appearance of the manuscript.

\section{ACKNOWLEDGMENTS}

The Ministry of Education Science and Technological Development of the Republic of Serbia has funded this study through Grant OI 175014. Publication of results was not contingent to Ministry's censorship or approval.

Getzen, T. E. (1990). Macro forecasting of national health expenditures. Adv. Health Econ. Health Serv. Res. 11, 27-48.

Gotseva, A. (2015). Reducing Public Spending at Private Expense? Out-of-Pocket Pharmaceutical Expenditure in Bulgaria after the 1998 Healthcare Reform. Doctoral dissertation, Central European University. Available online at: http:// www.etd.ceu.hu/2015/gotseva_adelina.pdf. (accessed October 15, 2015).

Healy, J., and McKee, M. (2002). Implementing hospital reform in central and eastern Europe. Health Policy 61, 1-19. doi: 10.1016/S0168-8510(01)00213-5

Higgins, M. J., and Graham, S. J. (2009). Intellectual property. Balancing innovation and access: patent challenges tip the scales. Science 326, 370-371. doi: $10.1126 /$ science. 1176116

Iskrov, G., Miteva-Katrandzhieva, T., and Stefanov, R. (2012). Challenges to orphan drugs access in Eastern Europe: the case of Bulgaria. Health Policy 108, 10-18. doi: 10.1016/j.healthpol.2012.08.013

Iskrov, G., and Stefanov, R. (2015). Prospects of risk-sharing agreements for innovative therapies in a context of deficit spending in bulgaria. Front. Public Health 3:64. doi: 10.3389/fpubh.2015.00064

Jakovljevic, M., Jovanovic, M., Lazic, Z., Jakovljevic, V., Djukic, A., and Velickovic, R. (2011). Current efforts and proposals to reduce healthcare costs in Serbia. Serb. J. Exp. Clin. Res. 12, 161-163. doi: 10.5937/sjecr1104161J

Jakovljevic, M., and Laaser, U. (2015). Population aging from 1950 to 2010 in seventeen transitional countries in the wider region of South Eastern Europe. Serb. J. Exp. Clin. Res. doi: 10.4119/UNIBI/SEEJPH-2015-49. [Epub ahead of print]. 
Jakovljevic, M., Rankovic, A., Rancic, N., Jovanovic, M., Ivanovic, M., Gajovic, O., et al. (2013). Radiology services costs and utilization patterns estimates in Southeastern Europe-A retrospective analysis from Serbia. Value Health Regional Issues 2, 218-225. doi: 10.1016/j.vhri.2013.07.002

Jakovljevic, M. D., Vukovic, M., and Fontanesi, J. (2015c). Life expectancy and health expenditure evolution in eastern Europe - DiD and DEA analysis. Exp. Rev. Pharmacoecon. Outcomes Res. doi: 10.1586/14737167.2016.1125293. [Epub ahead of print].

Jakovljevic, M., Yamada, T., Chen, C. C., Stevanovic, D., Jovanovic, M., Djuricic-Nikic, K., et al. (2015a). Cost-effectiveness of depressive episode pharmacological treatment. Hosp. Pharmacol. 2, 235-245.

Jakovljevic, M., Zugic, A., Rankovic, A., and Dagovic, A. (2014a). Radiation therapy remains the key cost driver of oncology inpatient treatment. J. Med. Econ. 18, 29-36. doi: 10.3111/13696998.2014.971162

Jakovljevic, M. B. (2013). Resource allocation strategies in Southeastern European health policy. Eur. J. Health Econ. 14, 153-159. doi: 10.1007/s10198-012-0439-y

Jakovljevic, M. B. (2014a). Health expenditure dynamics in Serbia 1995-2012. Hosp. Pharmacol. 1, 180-183.

Jakovljevic, M. B. (2014b). Oncology monoclonal antibodies expenditure trends and reimbursement projections in the emerging Balkan market. Farmeconomia Health Econ. Ther. Pathways 15, 27-32. doi: 10.7175/fe.v15i1.909

Jakovljevic, M. B., and Milovanovic, O. (2015). Growing burden of noncommunicable diseases in the emerging health markets: the case of BRICS. Front. Public Health 3:65. doi: 10.3389/fpubh.2015.00065

Jakovljevic, M. B., Djordjevic, N., Jurisevic, M., and Jankovic, S. (2015d). Evolution of the Serbian pharmaceutical market alongside socioeconomic transition. Expert Rev. Pharmacoecon. Outcomes Res. 15, 521-530. doi: 10.1586/14737167.2015.1003044

Jakovljevic, M. B., Jovanovic, M., and Lesch, M. O. (2015b). Accessibility and affordability of alcohol dependency medical care in Serbia. Front. Psychiatry 5:192. doi: 10.3389/fpsyt.2014.00192

Jakovljevic, M. B., Nakazono, S., and Oqura, S. (2014b). Contemporary generic market in Japan - key conditions to successful evolution. Expert Rev. Pharmacoecon. Outcomes Res. 14, 181-194. doi: 10.1586/14737167.2014.881254

Jakovljevic, M. M. (2016). Comparison of historical medical spending patterns among the BRICS and G7. J. Med. Econ. 19, 70-76. doi: 10.3111/13696998.2015. 1093493

Kornai, J., and Eggleston, K. (2001). Welfare, Choice and Solidarity in Transition: Reforming the Health Sector in Eastern Europe. New York, NY: Cambridge University Press. doi: 10.1017/CBO9780511492464

Krajewski-Siuda, K., and Romaniuk, P. (2006). Privatisation of hospitals in Poland-barriers and opportunities. Cent. Eur. J. Public Health 14, 25-29.

Mackenbach, J. P. (2006). Health Inequalities: Europe in Profile. Produced by COI for the Department of Health. Available online at: http://www.who.int/ social_determinants/resources/european_inequalities.pdf. (accessed October 15, 2015).

Mossialos, E., Mrazek, M., and Walley, T. (2004). Regulating Pharmaceuticals In Europe: Striving For Efficiency, Equity And Quality: Striving for Efficiency, Equity and Quality. Berkshire: McGraw-Hill Education.

Mossialos, E., and Oliver, A. (2005). An overview of pharmaceutical policy in four countries: France, Germany, the Netherlands and the United Kingdom. Int. J. Health Plann. Manage. 20, 291-306. doi: 10.1002/hpm.816

Mrazek, M., de Jonchere, K., Petrova, G., and Mossialos, E. (2004). The Pharmaceutical Sector and Regulation in the Countries of Central and Eastern Europe. Regulating Pharmaceuticals in Europe: Striving for Efficiency, Equity and Quality. Copenhagen: European observatory on health systems and policies, 323-333. Available online at: http://www.euro.who.int/_data/assets/pdf_file/ 0008/98432/E83015.pdf. (accessed October 15, 2015).
Nuijten, M. J. C., Berto, P., Berdeaux, G., Hutton, J., Fricke, F. U., and Villar, F. A. (2001). Trends in decision-making process for pharmaceuticals in Western European countries. Eur. J. Health Econ 2, 162-169. doi: 10.1007/s10198-0010079-0

OECD Pharmaceutical Spending (2013). Availbele online at: https://data.oecd.org/ healthres/pharmaceutical-spending.htm. (accessed October 15, 2015).

Ogura, S., and Jakovljevic, M. (2014). Health financing constrained by population aging - an opportunity to learn from Japanese experience. Serb. J. Exp. Clin. Res. 15, 175-181. doi: 10.2478/sjecr-2014-0022

Petrusic, T., and Jakovljevic, M. (2015). Budget impact of publicly reimbursed prescription medicines in the republic of Srpska. Front. Public Health 3:213. doi: $10.3389 /$ fpubh.2015.00213

Putrik, P., Ramiro, S., Kvien, K. T., Sokka, T., Pavlova, M., Uhlig, T., et al. (2014). Inequities in access to biologic and synthetic DMARDs across 46 European countries. Ann. Rheum. Dis. 73, 198-206. doi: 10.1136/annrheumdis-2012202603

Ranković, A., Rancić, N., Jovanovic, M., Ivanović, M., Gajović, O., Lazić, Z., et al. (2013). Impact of imaging diagnostics on the budget-are we spending too much? Vojnosanitetski Pregl. 70, 709-711.

Rémuzat, C., Urbinati, D., Mzoughi, O., Hammi, E. E., Belgaied, W., and Toumi, M. (2015). Overview of external reference pricing systems in Europe. J. Market Access Health Policy 3, 27675. doi: 10.3402/jmahp.v3.27675

Rhodes, T., Ball, A., Stimson, V. G., Kobyshcha, Y., Fitch, C., Pokrovsky, V., et al. (1999). HIV infection associated with drug injecting in the newly independent states, eastern Europe: the social and economic context of epidemics. Addiction 94, 1323-1336. doi: 10.1046/j.1360-0443.1999.94913235.x

Robinson, A. (1994). Rationale for cost-effective laboratory medicine. Clin. Microbiol. Rev. 7, 185-199.

Semashko, N. A. (1934). Health Protection in the USSR, 1st Edn. London: Victor Gollancz.

Simoens, S., and De Coster, S. (2006). Sustaining generic medicines markets in Europe. J. Generic Med. 3, 257-268. doi: 10.1057/palgrave.jgm.4940128

Tambor, M., Pavlova, M., Golinowska, S., and Groot, W. (2015). Can european countries improve sustainability of health care financing through patient cost-sharing? Front. Public Health 3:196. doi: 10.3389/fpubh.2015. 00196

The World Bank. Country and Lending Groups (2015). Available online at: http:// data.worldbank.org/about/country-and-lending-groups\#Upper_middle_ income. (accessed October 15, 15).

Torosyan, A., Romaniuk, P., and Krajewski-Siuda, K. (2008). The Armenian healthcare system: recent changes and challenges. J. Public Health 16, 183-190. doi: 10.1007/s10389-007-0160-y

World Health Organization, European Health for All database (HFA-DB) (2015). Available online at: http://www.euro.who.int/en/data-and-evidence/ databases/european-health-for-all-database-hfa-db. (accessed October $15,15)$.

Conflict of Interest Statement: The authors declare that the research was conducted in the absence of any commercial or financial relationships that could be construed as a potential conflict of interest.

Copyright (c) 2016 Jakovljevic, Lazarevic, Milovanovic and Kanjevac. This is an open-access article distributed under the terms of the Creative Commons Attribution License (CC BY). The use, distribution or reproduction in other forums is permitted, provided the original author(s) or licensor are credited and that the original publication in this journal is cited, in accordance with accepted academic practice. No use, distribution or reproduction is permitted which does not comply with these terms. 